\title{
Pengaruh Pemanfaatan Koleksi Fiksi Terhadap Minat Baca Anak Didik Lapas (Andikpas) Di Perpusatakaan Lembaga Pembinaan Khusus Anak (LPKA) Klas 1 Palembang
}

\author{
Mutiara Aisya ${ }^{*}$; Budhi Santoso ${ }^{2}$ \\ ${ }^{1,2}$ Prodi Ilmu Perpustakaan, UIN Raden Fatah Palembang \\ *Korespondensi: mutiaraaisya @gmail.com
}

\begin{abstract}
This study aims to examine the interest in reading fiction collections of students in the Special Child Development Institution (LPKA). This type of research is quantitative descriptive research. Data collection is done by observation, questionnaires, and documentation. The sample in the study was 145 respondents with descriptive analysis techniques. The results of the study showed that the variable Utilization of Fiction Collections in the Library of the Special Guidance for Children Class I Palembang with a value of 3.94 between the intervals of $3.43-4.23$ was categorized as High. Furthermore, the results showed that the variable of reading interest in the Library of the Special Guidance for Children Class I Palembag with a value of 3.73 between the intervals of 3.43-4.23 was categorized as high. Based on the results of the study, the influence of fiction collections on reading interest in the library of special development institutions for children of class I Palembang has a value of 0.776 in the interval coefficient score of 0.60-0.799 is called high. Based on the results of this study, the variable utilization of the collection of fiction has a positive and significant effect on reading interest in the library of a special coaching institution for class I children in Palembang. To make the library even better, it is recommended that the library can make efforts to add the latest collections of fiction every year so that the reading interest of prison students increases.
\end{abstract}

Keywords: Fiction Collections; Reading Interest; collection utilization

\begin{abstract}
Abstrak
Penelitian ini bertujuan untuk meneliti minat baca koleksi fiksi anak didik lapas Lembaga pembinaan khusus anak (LPKA). Jenis Penelitian ini adalah penelitian deskritif kuantitatif. Pengumpulan data dilakukan dengan observasi,kuesioner, dan dokumentasi. Sampel dalam penelitian sebanyak 145 responden dengan teknik Analisis Deskritif. Hasil Penelitian menunjukan variabel Pemanfaatan Koleksi fiksi di Perpustakaan Lembaga Pembinaan Khusus Anak Klas I Palembang dengan nilai 3,94 diantara interval 3,43 - 4,23 di kategorikan Tinggi. Selanjutnya hasil penelitian menunjukan variabel Minat Baca di Perpustakaan Lembaga Pembinaan Khusus Anak Klas I Palembag dengan nilai 3,73 di antara interval 3,43- 4,23 dikategorikan Tinggi. Berdasarkan hasil penelitian bahwa pengaruh koleksi fiksi terhadap minat baca di perpustakaan lembaga pembinaan khusus anak klas I Palembang memiliki nilai 0,776 dalam interval koefisien skor 0,600,799 disebut tinggi. Berdasarkan hasil penelitian ini, bahwa variabel pemanfaatan koleksi fiksi berpengaruh positif dan signifikan terhadap minat baca di perpustakaan lembaga pembinaan khusus anak klas I Palembang. Untuk menjadikan perpustakaan lebih baik lagi disarankan perpustakaan dapat melakukan upaya menambah koleksi-koleksi fiksi terbaru setiap tahunnya agar minat baca anak didik lapas menjadi semakin meningkat
\end{abstract}

Kata Kunci: Pemanfaatan Koleksi Fiksi; Minat Baca; pemanfaatan koleksi

\section{PENDAHULUAN}

Membaca adalah suatu proses kebiasaan yang jika dilakukan terus menerus akan menambah wawasan dan pengetahuan (Prianto 2020), semakin banyak melakukan kegiatan membaca maka akan semakin banyak kita mendapatkan penjelasan mengenai hal-hal yang belum kita ketahui, hanya dengan membaca kita dapat mengetahui, mengenal, merasakan dunia tanpa harus benar- 
benar pergi keliling dunia. Kebiasaan membaca merupakan sebuah interaksi antara pembaca dengan bahan bacaan secara teratur atau berulang. Minat baca akan menjadi kebiasaan membaca jika tersedia bahan bacaan yang sesuai untuk dibaca dan ada cukup waktu untuk membaca.

Minat baca menjadi salah satu tolak ukur kemajuan bangsa (Nafisah 2016), untuk meningkatkan minat baca masyarakat jika ada kesadaran untuk membaca dan ada beberapa pihak yang terlibat dalam peningkatan minat baca, yaitu peran pemerintah dan perpustakaan. Adapun faktor yang mendukung peningkatan minat baca salah satunya hasil pembinaan dan latihan. Pembiaan dan pelatihan dapat dilakukan oleh perpustakaan yaitu dengan menyediakan bahan bacaan yang menarik dan menyedikan layanan yang optimal. Menyediaan bahan bacaan yang menarik tentu akan menarik minat pengguna perpustakaan untuk menggunakan koleksi yang dilayankan perpustakaan.

Perpustakaan mempunyai beberapa segmentasi pengguna tergantung kepada jenis perpustakaanya, Menurut prastowo (2018) perpustakaan dibagi menjadi beberapa jenis yaitu; perpustakaan nasional, perpustakaan umum, perpustakaan khusus, perpustakaan perguruan tinggi, perpustakaan sekolah/madrasah dll. Adapun jenis perpustakaan ini akan mempengaruhi jenis koleksi yang ada diperpustakaan. Perpustakaan khusus adalah salah satu jenis perpustakaan yang dibentuk oleh lembaga (pemerintah/swasta) atau perusahaan yang mempunyai misi tertentu dengan tujuan untuk memenuhi kebutuhan lingkungannya, baik dalam hal pengelolaan maupun pelayanan informasi bahan pustaka dalam rangka mendukung pengembangan dan peningkatan tugas dan fungsi lembaga yang bersangkutan maupun sumber daya manusianya (Martoatmojo 1999).

Lembaga Pembinaan Khusus Anak (LPKA) Klas 1 Palembang memiliki perpustakaan khusus yang melayani 145 warga binaan, yang termasuk warga binaan di lapas ini menurut undang-undang nomor 12 tahun 1995 (1995) tentang pemasyarakatan menjelaskan bahwa anak pidana adalah anak yang sudah berusia dua belas tahun dan berdasarkan putusan pengadilan menjalani pidana dilembaga pemasyarakatan anak paling lama sampai berumur 18 tahun. Sebagai perpustakaan khusus anak, perpustakaan ini menyediakan koleksi yang berupa koleksi fiksi dan koleksi non fiksi. Berdasarkan hasil observasi peneliti buku yang paling banyak dipinjam oleh warga binaan adalah buku fiksi, buku fiksi ini dapat berupa buku cerita, buku dongeng, buku cerpen, novel dan lain-lain. Oleh karena itu, penulis tertarik untuk meneliti apakah koleksi fiksi berpengaruh dalam meningkatkan minat baca bagi anak binaan di LPKA Klas 1 Palembang.

\section{METODE PENELITIAN}

Jenis Penelitian yang digunakan adalah deskriptif kuantitatif. Populasi dalam penelitian ini adalah seluruh anak binaan lembaga pembinaan khusus anak klas I Palembang, dengan populasi berjumlah 145 anak binaan. Sementara itu, peneliti mengambil metode sampel jenuh. Sampel jenuh adalah teknik penentuan sampel bila semua anggota populasi digunakan sebagai sampel. Dalam penelitian ini peneliti mengambil 145 sampel anak binaan. Skala pengukuran dari tiap pernyataan yang digunakan dalam penelitian ini ialah menggunakan skala likert, yang mana kuesioner dalam penelitian ini terdiri dari pernyataan positive dan pernyataan negative (Sugiyono 2016).

Sedangkan, pilihan jawaban yang peneliti gunakan dalam penelitian ini yakni sangat setuju, setuju, tidak setuju, sangat tidak setuju. Dengan pemberian skor untuk SS diberi skor 5, S diberi skor 4, RR diberi skor 3, TS diberi skor 2, STS diberi skor 1 (Habiby 2017). Teknik analisis data yang digunakan dalam menganalisis penelitian ini yaitu menggunakan teknik analisis deskritif 
kuantitatif (Yusuf 2017), dengan melakukan uji regresi linier sederhana, uji t dan melihat nilai koefisien determinasi untuk menganalisis variabel bebas yaitu Pemanfaatan Koleksi Fiksi terhadap Variabel terikat yaitu Minat Baca.

\section{HASIL DAN PEMBAHASAN}

Dalam penelitian ini terdapat hasil temuan yang menunjukan bahwa pemanfaatan koleksi fiksi yang dialami oleh anak didik lapas lembaga pembinaan khusus anak klas I Palembang dikategorikan tinggi dengan nilai 3,94 yang terdiri dari indikator kebutuhan sebesar 4,10; Motif sebesar 4,08; minat 3,90 ; kelengkapan koleksi 3,81; Keterampilan pustakawan 3,78; ketersediaan fasilitas ; 4,05. Dari perhitungan setiap nilai rata-rata dari variabel pemanfaatan koleksi fiksi (X) tersebut membuktikan bahwa nilai rata-rata paling tinggi terdapat pada sub variabel kebutuhan yang jumlah skor rata-ratanya sebesar 4,10. Hal tersebut bahwa pada pemanfaatan koleksi fiksi yang dialami anak binaan termasuk dalam kategori tinggi.

\section{Tabel 1}

Analisis pemanfaatan koleksi fiksi Anak Didik Lapas (Andikpas)

\begin{tabular}{cccc}
\hline No & Sub Variabel & $\begin{array}{c}\text { Nilai Rata- } \\
\text { Rata }\end{array}$ & Kategori \\
\hline A & Kebutuhan & $\mathbf{4 , 1 0}$ & Tinggi \\
B & Motif & $\mathbf{4 , 0 8}$ & Tinggi \\
C & Minat & $\mathbf{3 , 9 0}$ & Tinggi \\
D & Kelengkapan Koleksi & $\mathbf{3 , 8 1}$ & Tinggi \\
E & Keterampilan pustakawan terhadap & $\mathbf{3 , 7 8}$ & Tinggi \\
& pemustaka & & \\
F & Ketersediaan Fasilitas & $\mathbf{4 , 0 5}$ & Tinggi \\
\hline
\end{tabular}

Berdasarkan tabel diketahui bahwa sub variabel kebutuhan nilai rata-ratanya 4,10, Sub Variabel Motif Nilai rata-rata nya 4,08, Sub Variabel Minat nilai rata-ratanya 3,90, sub variabel Kelengkapan Koleksi nilai rata-rata nya 3,81, sub variabel keterampilan Pustakawan terhadap Pemustaka nilai rata-ratanya 3,78, sub variabel Ketersediaan Fasilitas nilai rata-ratanya 4,05. Dengan Demikian Berdasarkan Hasil nilai rata-rata tersebut dapat diketahui bahwa total nilai grand mean keseluruhannya adalah :

$$
\text { Grand Mean }(x)=\frac{\text { Total rata }- \text { rata hitung }}{\text { Jumlah pernyataan }}=\frac{78,94}{6}=3,94
$$

Dari hasil perhitunga keenam sub variabel tersebut, maka diperoleh bahwa pemanfaatan koleksi fiksi terhadap minat baca anak didik lapas (andikpas) di Perpustakaan Lembaga Pembinaan Khusus Anak Klas I Palembang tergolong dalam kategori tinggi dengan nilai rata-rata 3,94 da berada di interval 3,23-4,32.

Sedangkan Perhitungan skor rata-rata variabel minat baca $(Y)$ yaitu sebesar 3,73 dengan sub variabel perasaan senang membaca sebesar 3,60, Membaca kebutuhan, bukan paksaan sebesar 4,16, frekuensi membaca sebesar 3,22, kuantitas sumber bacaan 3,85. Dari perhitungan setiap skor rata-rata dari varibael (Y) minat baca perpustakaan tersebut membuktikan bahwa skor rata-rata tertinggin terdapat pada membaca kebutuhan bukan paksaan mengenai sebsar sebesar 
4,16. Hal tersebut menunjuikan bahwa minat baca di perpustakaan lembaga pembinaan khusus anak klas I Palembang dikategorikan tinggi atau baik.

\section{Tabel 2}

Analisis Minat Baca Anak Didik Lapas (Andikpas)

\begin{tabular}{cccc}
\hline No & Sub Variabel & $\begin{array}{c}\text { Nilai Rata- } \\
\text { Rata }\end{array}$ & Kategori \\
& & $\mathbf{3 , 6 0}$ & Tinggi \\
\hline A & Perasaan Senang membaca buku & $\mathbf{4 , 1 6}$ & Tinggi \\
B & Membaca Kebutuhan, Bukan Paksaan & $\mathbf{3 , 2 2}$ & Sedang \\
C & Frekuensi Membaca & $\mathbf{3 , 8 5}$ & Tinggi \\
D & Kuantitas Sumber Bacaan & & \\
\hline
\end{tabular}

Berdasarkan diketahui bahwa sub variabel Perasaan senang membaca buku nilai rata-ratanya 3,60, Sub Variabel Membaca kebutuhan, bukan paksaan Nilai rata-rata nya 4,16, Sub Variabel Frekuensi Membaca nilai rata-ratanya 3,22 sub variabel Kuantitas sumber bacaan nilai rata-rata nya 3,85. Dengan Demikian Berdasarkan Hasil nilai rata-rata tersebut dapat diketahui bahwa total nilai grand mean keseluruhannya adalah :

$$
\text { Grand Mean }(x)=\frac{\text { Total rata }- \text { rata hitung }}{\text { Jumlah pernyataan }}=\frac{44,82}{4}=\mathbf{3 , 7 3}
$$

Dari hasil perhitunga keenam sub variabel tersebut, maka diperoleh bahwa pemanfaatan koleksi fiksi terhadap minat baca anak didik lapas (andikpas) di Perpustakaan Lembaga Pembinaan Khusus Anak Klas I Palembang tergolong dalam kategori tinggi dengan nilai rata-rata 3,73 da berada di interval 3,23-4,32.

Selanjutnya Hasil Analisa Data Pengaruh Pemanfaatan Koleksi Fiksi Terhadap Minat Baca Anak Didik Lapas (Andikpas) di Perpustakaan Lembaga Pembinaan Khusus Anak Klas I Palembang.

\section{Uji Regresi Linier Sederhana}

Bersumber pada pengolahan data yang telah dilakukan, di peroleh koefisien regresi sebagai berikut :

Tabel 3.

Hasil Perhitungan uji regresi

\begin{tabular}{|c|c|c|c|c|c|c|c|}
\hline \multirow[b]{2}{*}{ Model } & \multicolumn{3}{|c|}{$\begin{array}{l}\text { Unstandardized } \\
\text { Coefficients }\end{array}$} & \multicolumn{2}{|c|}{$\begin{array}{l}\text { Standardized } \\
\text { Coefficients }\end{array}$} & \multirow[b]{2}{*}{$\mathrm{T}$} & \multirow[b]{2}{*}{ Sig. } \\
\hline & $\mathrm{B}$ & Std. & Error & Beta & & & \\
\hline (Constant) & 15.135 & & 4.590 & & & 3.297 & .001 \\
\hline $\begin{array}{l}\text { Pemanfaatan Koleksi } \\
\text { Fiksi }\end{array}$ & 1.375 & .158 & .898 & 6.473 & .000 & & \\
\hline
\end{tabular}

a. Dependent Variable: Minat Baca

Berdasarkan hasil tabel olah data menggunakan SPSS v22.0 diatas nilai konstanta sebesar 15,135 menyatakan bahwa jika nilai $\mathrm{X}=0$ atau dengan kata lain variabel pemanfaatan koleksi fiksi tidak ada peningkatan atau konstan, maka nilai variabel pemafaatan koleksi fiksi akan tetap sebesar 15,135. Koefisien regresi variabel pemanfaatan koleksi fiksi sebesar -1,375 yang berarti bahwa setiap nilai 
pemanfaatan koleksi fiksi meningkat $1 \%$, maka nilai minat baca akan meningkat sebesar $-0,1375$. Karena koefisien regresi tersebut bernilai negative maka dapat diartikan bahwa dengan semakin meningkatnya pemanfaataan koleksi fiksi maka akan semakin rendah minat baca anak binaan, berlaku pula sebaliknya. Dengan demikian dapat diartikan bahwa dari pemanfaatan koleksi fiksi berpengaruh positif tehadap minat baca.

\section{Uji Hipotesis}

Berdasarkan hasil uji analisis menggunakan IBM SPSS versi 22.0 di peroleh hasil seperti yang terdapat pada tabel berikut :

Tabel 4.

Uji Hipotesis (Uji-t)

\begin{tabular}{llrr}
\multicolumn{1}{c}{ Model } & T & Sig. \\
\hline 1 (Constant) & 3.297 & .001 \\
\multicolumn{2}{c}{ Pemanfaatan Koleksi Fiksi } & 6.473 & .000 \\
\hline
\end{tabular}

Sumber: Hasil Perhitungan dengan SPSS

Berdasarkan pada tabel diatas di peroleh t hitung sebesar 3.297 pada tingkat signifikan sebesar 0,001. Adapun kriteria pengujian hipotesis dalam penelitian ini, yaitu $\mathrm{H}_{0}$ : tidak ada pengaruh pemanfaatan koleksi fiksi terhadap minat baca di perpustakaan lembaga pembinaan khusus anak klas I Palembang, $\mathrm{H}_{\mathrm{a}}$ : terdapat pengaruh pemanfaatan koleksi fiksi terhadap minat baca anak di perpustakaan lembaga pembinaan khusus anak klas I Palembang .

Hasil dari Perhitungan diatas diketahui Variabel Pemanfaatan Koleksi Fiksi menunjukkan nilai thitung lebih besar dari tabel $(6,473>1,976)$ atau sig $<\alpha(0.000<0.05)$, berarti variabel pemanfaatan koleksi fiksi berpengaruh terhadap minat baca anak didik lapas di Perpustakaan Lembaga Pembinaan Khusus Anak (LPKA) Klas 1 Palembang, dengan demikian dapat disimpulkan bahwa hipotesis atau $\mathrm{H}_{1}$ diterima.

\section{Analisis Koefisien Determinasi $\left(\mathbf{R}^{2}\right)$}

Koefisien determinasi merupakan besaran yang menunjukkan besarnya variabel-variabel dependen yang dapat dijelaskan oleh variabel independennya. Dengan kata lain, koefisien ini digunakan untuk mengukur seberapa jauh variabel bebas dalam menerangkan variabel terikatnya. 
Tabel 5

Analisis Koefisien Determinasi

\begin{tabular}{lrrrr} 
Model & R & R Square & \multicolumn{1}{c}{$\begin{array}{c}\text { Adjusted R } \\
\text { Square }\end{array}$} & $\begin{array}{c}\text { Std. Error of the } \\
\text { Estimate }\end{array}$ \\
\hline 1 & $.898^{\mathrm{a}}$ & .773 & .767 & 1.7813
\end{tabular}

Tabel di atas menjelaskan besarnya nilai korelasi/hubungan $(\mathrm{R})$ yaitu sebesar 0,898 dan diperoleh koefisien determinasi (R Square) sebesar 0,773. Hal ini berarti bahwa pengaruh variabel bebas (pemanfaatan koleksi fiksi) mempunyai kontribusi sebesar 77,3\% terhadap variabel terikat (minat baca), sementara sisanya sebesar $22,7 \%$ dijelaskan oleh faktor-faktor lain diluar dari penelitian ini.

\section{SIMPULAN}

Berdasarkan hasil analisis data penelitian yang telah dilakukan mengenai pengaruh pemanfaatan koleksi fiksi terhadap minat baca anak didik lapas di Perpustakaan Lembaga Pembinaan Khusus Anak (LPKA) Klas 1 Palembang, maka dapat disimpulkan sebagai berikut:

Pemanfaatan koleksi fiksi di Perpustakaan Lembaga Pembinaan Khusus Anak (LPKA) Klas 1 Palembang berdasarkan nilai dari keseluruhan indikator yang dihitung dengan menggunakan rumus grand mean yaitu sebesar 3,94 termasuk dalam kategori tinggi.

Minat baca anak didik lapas di Perpustakaan Lembaga Pembinaan Khusus Anak (LPKA) Klas 1 Palembangberdasarkan nilai dari keseluruhan indikator yang dihitung dengan menggunakan rumus grand mean yaitu sebesar 3,73 termasuk dalam kategori tinggi.

Terdapat pengaruh positif antara pemanfaatan koleksi fiksi terhadapminat baca anak didik lapas di Perpustakaan Lembaga Pembinaan Khusus Anak (LPKA) Klas 1 Palembang. Hal ini dibuktikan oleh hasil uji hipotesis (ttest) dengan nilai koefisien sebesar 6,473 maka thitung $>t_{\text {tabel }}$ pada taraf signifikan 0,05 (1,976). Hasil tersebut menunjukkan bahwa pemanfaatan koleksi fiksi berpengaruh terhadap minat baca anak didik lapas dan bernilai positif, artinya semakin tinggi pemanfaatan koleksi fiksi yang dimanfaatkan anak didik lapasmaka semakin tinggi pula minat baca anak didik lapas. Adapun nilai koefisien determinasi besar pengaruh pemanfaatan koleksi fiksi terhadap minat baca anak didik lapas dapat dilihat dari nilai koefisien determinasi $\left(\mathrm{R}^{2}\right)$ atau $\mathrm{R}_{\text {square }}$ sebesar 0,773 atau 77,3\%. Hal ini berarti bahwa 77,3\% variasi minat baca anak didik lapas di Perpustakaan Lembaga Pembinaan Khusus Anak (LPKA) Klas 1 Palembang dipengaruhi oleh pemanfaatan koleksi fiksi, sedangkan sisanya sebesar $22,7 \%$ merupakan pengaruh dari faktor lain di luar faktor yang diteliti. 
Mutiara Aisya1; Budhi Santoso/ Pengaruh Pemanfaatan Koleksi Fiksi Terhadap Minat Baca Anak Didik Lapas (Andikpas) Di Perpusatakaan Lembaga Pembinaan Khusus Anak (LPKA) Klas 1 Palembang

\section{DAFTAR PUSTAKA}

Habiby, Wahdan Najib. 2017. Statistika Pendidikan. Surakarta: Muhammadiyah University Press.

Martoatmojo, Karmidi. 1999. Manajemen Perpustakaan Khusus. Jakarta: Universitas Terbuka.

Nafisah, Aliyatin. 2016. 'ARTI PENTING PERPUSTAKAAN BAGI UPAYA PENINGKATAN

MINAT BACA MASYARAKAT’. LIBRARIA: Jurnal Perpustakaan 2(2). doi:

10.21043/libraria.v2i2.1248.

Prastowo, Andi. 2018. Sumber Belajar \& Pusat Sumber Belajar Teori Dan Aplikasinya Disekolah/Madrasah. Depok: Prenadamedia Group.

Prianto, Joko Sugeng. 2020. 'BUDAYA BACA UNTUK KEMAJUAN SUATU BANGSA'. Buletin Perpustakaan 0(0):1-20.

Republik Indonesia. 1995. Undang-Undang Republik Indonesia Nomor 12 Tahun 1995.

Sugiyono. 2016. Metode Penelitian Kuantitatif Kualitatif Dan R \& D. Bandung: Alfabeta.

Yusuf, M. 2017. Metode Penelitian: Kuantitatif, Kualitatif Dan Penelitian Gabungan. Jakarta:

Kencana. 